\title{
ИНСТИТУЦИОНАЛЬНАЯ СТРУКТУРА И ИСТОЧНИКИ ПРАВА ЕС И МЕРКОСУР: СРАВНИТЕЛЬНО-ПРАВОВОЙ АСПЕКТ
}

\begin{abstract}
Аннотация. В настоящей статье исследованию в сравнительном аспекте подвергаются институииональная структура и источники права ЕС и МЕРКОСУР. В ходе исследования автор выявляет ожидаемый вектор развития институциональной структуры подобных МЕРКОСУР интеграционных структур. Методы исследования, используемые автором, - сравнительно-правовой, исторический, диалектический, специально-научные. Методология исследования - представление об объективносубъективной заданности любых проиессов. В качестве предмета исследования выбрано, с одной стороны, интеграционное объединение, имеющее давнюю историю, - Европейский Союз, с другой, -не наднациональная структура, имеющая не столь давнюю историю, но наиболее успешное и наиболее развитое в Южной Америке.
\end{abstract}

Ключевые слова: Международное право, экономическая, интеграция, ЕС, МЕРКОСУР, институичинальная, структура, наднациональные, акты, институцииализация

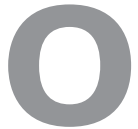

дной из главных тенденций мирового развития в настоящее время является интеграция государств, основывающаяся на тесном сотрудничестве и приспособлении национальных хозяйств к новым мировым отношениям; являющаяся объединением материальных, организационных, финансовых, трудовых и интеллектуальных ресурсов отдельных стран. Учреждаясь как организации локального региона с целью образования Зоны свободной торговли, Таможенного союза, Общего рынка, интеграционные объединения имеют тенденцию к расширению территории за счет присоединяющихся к ним других государств этого же региона. Примерами интеграции континентального масштаба являются: в Европе - Европейский союз (далее - ЕС), зародившийся как Европейское экономическое сообщество (ЕЭС) в пределах территории 6 западноевропейских стран и расширившийся за более, чем 50-летний период своего существования до 27 государств; в Северной Америке - Североамериканская зона свободной торговли (НАФТА), ${ }^{1}$ в Южной Америке - Южноамериканский общий рынок (МЕРКОСУР), учрежденный 4 странами и расширившийся за

\footnotetext{
${ }^{1} 1$ января 2008 г. истек официальный 15-летний срок, на который было рассчитано Соглашение о североамериканской зоне свободной торговли, так что формально Соглашение считается выполненным.
}

более, чем 20-летний период существования за счет ассоциированных членов до 10 государств. ${ }^{2}$ В 2012 г. произошли события, изменившие состав МЕРКОСУР. В декабре 2012 г. был подписан Протокол о присоединении к МЕРКОСУР в качестве полноправной страны-участницы Боливии, ${ }^{3}$ pa-

\footnotetext{
${ }^{2}$ См., напр., Беликова К.M. На пути к единому рынку в Южной Америке: факторы интеграции в экономике и праве. // Вестник Российского университета дружбы народов. Серия «Юридические науки». - 2005. - № 1. - С. 83-89; Безбах В.В., Беликова К.M. Что заставляет латиноамериканцев объединяться? Образование Южноамериканского Общего рынка и его развитие. // Внешнеторговое право. - 2006. - № 1(6). - С. 8-12; Беликова К.М. Общий рынок в Европе: интеграция и дифференциация. // Международное публичное и частное право. - 2005. - № 1 (22). - С. 14-17; Она же. Правовое регулирование торгового оборота и кодификация частного права в странах Латинской Америки. Монография / К.М. Беликова. - М.: Юстицинформ - 2010. - С. С. 87-102 (480 с.); Она же. Особенности правовой охраны конкурентной среды в Североамериканской зоне свободной торговли (НАФТА). // Сравнительное право и проблемы частноправового регулирования: Материалы научной конференции аспирантов кафедры гражданского и трудового права юридического факультета РУДН. Москва, 25 января 2008 г. Выпуск 8./ Сост. В.В. Безбах, Е.П. Ермакова, К.М. Беликова. - М.: МАКС Пресс, 2008. - C. 29-32

${ }^{3}$ Protocolo de Adhesión del Estado Plurinacional de Bolivia al MERCOSUR. 7/12/2012. URL: http://www.mercosur.int/innovaportal/file/2485/1/protocolo_adhesion_bolivia_al_mercosur.pdf (дата обращения: 09.01.2013)
} 
нее входившей в состав ассоциированных членов. А в июле 2012 г. полноправной страной-участницей МЕРКОСУР наконец стала Венесуэла, ${ }^{4}$ заняв место Парагвая, членство которого в МЕРКОСУР было прекращено согласно примененным положениям Протокола Монтевидео по вопросу приверженности демократии в МЕРКОСУР от 20 декабря 2011 г. - Ушуаи II $^{5}$ после того, как в Парагвае произошел государственный переворот. Враждебно настроенный к главе государства парламент при помощи процедуры импичмента сместил законно избранного президента Фернандо Арминдо Луго Мендеса. ${ }^{6}$

Особенность современной интеграционной практики в Европе состоит в расширении ЕС за счет присоединения стран с совершенно разными стартовыми возможностями и значительными различиями в их социально-экономической модернизации и стадий проводимых рыночных реформ, что характерно и для МЕРКОСУР, включающего в себя государства различного уровня развития.

МЕРКОСУР существует уже более 20 лет, однако, в сравнении с периодом существования ЕС это срок небольшой. На сегодняшний день МЕРКОСУР представляет собой наиболее успешное и наиболее развитое интеграционное объединение латиноамериканских стран, имеющее сходные черты в ЕС. Так, например, в августе 2010 г. на 39-й встрече на высшем уровне МЕРКОСУР был утвержден общий Таможенный кодекс, который должен завершить формирование Таможенного союза в рамках МЕРКОСУР.

В силу этого рассмотрение в сравнительном аспекте институциональной структуры ЕС и МЕРКОСУР и компетенции соответствующих органов этих объединений и принимаемых ими актов,

${ }^{4}$ См., напр., Venezuela se incorporó formalmente al Mercosur. 31 de julio de 2012. URL: http://www.lanacion.com.ar/1494926todo-listo-para-que-venezuela-se-incorpore-al-mercosur (дата обращения: 09.01.2013)

${ }^{5}$ Protocolo de Montevideo sobre Compromiso con la Democracia en el MERCOSUR (Ushuaia II). 20/12/2012. URL: http://www. mercosur.int/innovaportal/file/2485/1/ushuaia_ii.pdf(дата обращения: 09.01.2013). Eduardo Arce. Polémica en torno a la firma del Protocolo de Montevideo en el Mercosur. // E`a. Periodico de Interpretacion y Analisys. Enero 11, 2012. URL: http://ea.com. py/polemica-en-torno-a-la-firma-del-protocolo-de-montevideoen-el-mercosur/ (дата обращения: 09.01.2013)

${ }^{6}$ Моисеев А. Демократия дала сбой в Парагвае. // Международная жизнь. 16/07/2012. URL: http://ref.interaffairs.ru/read. php?item=8610 (дата обращения: 09.01.2013) являющееся предметом исследования в настоящей статье, позволит, на наш взгляд, определить ожидаемый вектор развития институциональной структуры подобных МЕРКОСУР интеграционных структур.

Институциональная структура ЕС достаточно хорошо освещена в отечественной литературе, ${ }^{7}$ в нашу задачу также не входит подробный анализ взглядов на проблему классификации источников права ЕС, высказанных в отечественной и зарубежной литературе. ${ }^{8}$ Применительно к ЕС рассматриваемый в настоящей статье вопрос будет затронут в объеме, необходимом и достаточном, на наш взгляд, для проведения аналогии с ситуацией, сложившейся к настоящему времени в рамках МЕРКОСУР.

Учитывая, что понятие «источник права» многозначно, ${ }^{9}$ при характеристике источников права ЕС и МЕРКОСУР, мы будем понимать его в традиционном смысле как форму выражения и закрепления правовых норм. За основу классификации источников возьмем наиболее распространенный в отечественной и зарубежной правовой литературе подход, согласно которому они подразделяются на «первичные» (originarios - исп.) и «вторичные» (derivados - исп.). ${ }^{10}$

\footnotetext{
${ }^{7}$ См., например, Основы европейского интеграционного права. [Текст] : учебник / авт. коллектив: А.Х. Абашидзе [и др.] ; под ред. д-ра юрид. наук, проф. А.Х. Абашидзе, д-ра юрид. наук, проф. А.О. Иншаковой. - М.: Изд-во «Юрист». -2012. - С. 34-57; Право Европейского Союза: учебн. пособие /С.Ю. Кашкин [и др.]; отв. ред. С.Ю. Кашкин. - М.: ТК Велби, Изд-во Проспект, 2008; Топорнин Б.Н. Европейское право: Учебник. - М.: Юристь, 2001. - С. 39-116, 264-452; Право Европейского Союза: правовое регулирование торгового оборота. Учебное пособие. / под ред. В.В. Безбаха, А.Я. Капустина, В.К. Пучинского. - М.: ЗЕРЦАЛО, 2000. - С. 10-22, 42-55 и др.

${ }^{8}$ Обзор взглядов отечественных и зарубежных ученых см., напр., Энтин М.Л. Суд Европейских сообществ. Правовые формы обеспечения западноевропейской интеграции. - М., 1987. - С. 25-37.

${ }^{9}$ Муромиев Г.И. Источники права ЕС. // Право Европейского Союза: правовое регулирование торгового оборота. Учебное пособие. / под ред. В.В. Безбаха, А.Я. Капустина, В.К. Пучинского. - М.: ЗЕРЦАЛО, 2000. - С. 44.

${ }^{10}$ См., например, Муромиев Г.И. Там же, с. 44; Топорнин Б.Н. Цит. соч., с. 277; Lavopa H. J. La dimensión juridica de la integración. // Contribuciones. - Buenos Aires, 1996. - A. 13, \# 4. - P. 149-189; Instituciones y derecho en los sistemas de integración. // Alonso Casellas C., Bozzo C., Ferro G.S., Gos L.A., Stabile M.R. Solución de controversias en los sistemas de integración. El caso del MERCOSUR. SERIE INAP-AAG. DNEYD - CEPAS. P. 16-32; Documentación del Seminario "Las normas de derecho originario y derivado del MERCOSUR.
} 
Институциональная структура $\boldsymbol{E C}$ устанавливается в п. 1 ст. 13 Консолидированной версии Договора о Европейском Союзе ${ }^{11}$ и включает в себя Европейский парламент и другие институты ЕС, Европейский совет, Совет, Европейскую комиссию, Европейский центральный банк и Счетную палату, Европейский суд правосудия. Все вместе эти институты образую институциональный механизм (institutional framework - англ.), который призван продвигать ценности Союза, содействовать достижению целей, ради которых создан Союз, служить интересам Союза, его граждан и стран-участниц $\mathrm{EC}$, и обеспечивать слаженность, эффективность и преемственность политик и действия других элементов названного механизма.

Европейский парламент - представительный орган, ведущий свое происхождение от Общей ассамблеи ЕОУС, учрежденной в 1951 г. Также назывались и аналогичные органы ЕЭС и Евратома, однако в 1958 г. единая Ассамблея европейских сообществ была провозглашена Парламентской ассамблеей, а в 1962 г. - Парламентом. Первоначально Ассамблея европейских сообществ занимала скромное положение в системе надгосударственных институтов, будучи преимущественно консультативным органом, хотя и располагала вместе с тем некоторыми властными полномочиями. В ст. 138 Договора о ЕЭС она характеризовалась как орган, осуществляющий полномочия по обсуждению и контролю, a ее права в законодательной сфере сводились лишь к представлению Совету и Комиссии необязательных по характеру заключений по проектам нормативных актов. С 70-ых гг. динамика развития этого института напоминает аналогичный процесс,

Su incorporación a los ordenamientos de los estados partes." Secretaría Administrativa del Mercosur (SAM), Montevideo, República Oriental del Uruguay 26 y 27 de septiembre de 2002; Ruesga Santos, M., Heredero, Ma Isabel y Fujii, Gerardo, Europa e Iberoamerica: dos escenarios de integración económica, Editorial Parte Luz, Madrid, 1998.

${ }^{11}$ Consolidated versions of the Treaty on European Union and the Treaty on the functioning of the European Union. // OJ C 83 of 30.3.2010. URL: http://eur-lex.europa.eu/JOHtml.do?uri=O J:C:2010:083:SOM:EN:HTML (дата обращения: 05.01.2013) Консолидированная версия содержит текст Договора о ЕС (Treaty on European Union) и Договора о функционировании ЕC (Treaty on the Functioning of the European Union), приложений и протоколов в редакции с учетом изменений, последовавших за принятием текста Лиссабонского договора (Treaty of Lisbon), подписанного 13 декабря 2007 г. происходивший в Средневековье и Новое время с национальными парламентами. ${ }^{12}$ Каждая последующая реформа учредительных договоров расширяла законодательные полномочия Европейского парламента таким образом, что со временем он превратился в один из законодательных органов $\mathrm{EC},{ }^{13}$ осуществляющий соответствующие функции при ведущей роли Совета.

В состав Совета EC входят представители от каждой страны-участницы на министерском уровне, он не имеет постоянного состава. В настоящее время Совет по общим вопросам собирается в составе министров иностранных дел и принимает решения внешнеполитического характера-в сфере отношений ЕС с третьими странами и по вопросам, затрагивающим все страны-участницы в целом. Специальные советы заседают в составе отраслевых министров в зависимости от соответствующей предметной компетенции. Совет собирается на заседания столько раз, сколько сочтет необходимым, однако обязан сделать это по требованию европейской комиссии либо любого члена Совета.

Несмотря на его состав в западноевропейской доктрине он традиционно характеризовался как главный законодательный орган ЕС, об этом же свидетельствовали положения ст. 207 Договора о ЕС (в ред. до принятия Лиссабонского соглашения 2007 г.). ${ }^{14}$ Основополагающее значение в сфере законодательной власти имели полномочия Совета на осуществление правового регулирования общественных отношений посредством издания нормативных актов. Наряду с законодательными функциями он осуществлял многие другие полномочия, в том числе, в сфере исполнительной власти, в частности, большие полномочия в сфере исполнительной власти закрепляются за Советом при координации общей экономической политики стран-участниц (ст. 202 Договора о ЕС (в ред. до принятия Лиссабонского соглашения 2007 г.)). В настоящее время Совет обеспечивает координацию

\footnotetext{
12 Право Европейского Союза: Учебник для вузов / под ред. С.Ю. Кашкина. - М.: Юристъ, 2002 - С. 254.

13 Об этом свидетельствует решение 1999 г. Европейского суда по правам человека по делу гражданки Великобританиижительницы Гибралтара об отказе ей в праве участвовать в выборах в Европарламент. - См. Там же. С. 254.

${ }^{14}$ Treaty on European Union (consolidated text). // Official Journal C 325 of 24 December 2002. URL: http://europa.eu.int/eur-lex/ en/treaties/dat/amsterdam.html (дата обращения: 10.02.2006)
} 
общей экономической и социальной политики и наделен правом принятия обязательных решений. Ежегодно по предложению Комиссии Совет утверждает своеобразный план экономического развития ЕС в целом и каждой отдельно взятой страны-участницы.

Комиссия ЕС ведет свое происхождение от Верховного органа ЕОУС, который в рамках первого из Европейских сообществ осуществлял как исполнительную, так и законодательную власть. Комиссия в западной литературе и средствах массовой информации традиционно характеризуется как орган, наделенный исполнительной властью, имеющий одновременно нормотворческие и квазисудебные полномочия.

В качестве исполнительного органа Комиссия применяет и проводит в жизнь решения, принимаемые Советом. В большинстве случаев на ней лежит обязанность детальной разработки нормативных актов, окончательное решение по которым принимается Советом. Полномочия по принятию решений могут быть Советом делегированы Комиссии, но в строго очерченных пределах. В определенных случаях, например, в области конкурентной политики, Комиссия обладает правом принятия собственных решений без дальнейшего утверждения их Советом, однако законодательная деятельность Комиссии в этом случае контролируется Советом. Полномочия в сфере законодательной инициативы в смысле разработки и предоставления предложений, направленных на достижение целей Договора, реализуются Комиссией как в рамках специальной, так и общей компетенции Комиссии. В соответствии с п. 3 ст. 4 Договора о ЕС государства-члены обязаны принимать все необходимые меры для соблюдения положений и обязательств, закрепленных в Договоре и установленных основными институтами ЕC, а также воздерживаться от действий, которые могли бы нарушить стабильность Договора. Наряду с указанными полномочиями Комиссия вправе осуществлять контроль и пресекать нарушения права ЕС странами-участницами. Со своей стороны государства-члены обязываются всячески содействовать праву ЕС для достижения максимальной эффективности.

Способ формирования Комиссии неоднократно менялся. Первоначально назначение членов Комиссии осуществлялось правительствами стран-участниц; в 90-ые гг. право решающего голоса в этом процессе приобрел Европейский парламент. В настоящее время Еврокомиссия формируется по принципу «один комиссар от каждой из стран-участниц ЕС», в это число включается и Председатель, кандидатура которого выдвигается Европейским советом большинством голосов, а утверждается Европарламентом.

Органы правосудия ЕС функционируют как единая судебная система, складывающаяся из нескольких звеньев, связанных друг с другом иерархическими отношениями. Первоначально единственное, а в настоящее время высшее звено - Суд $E C$ - функционирует с 1952 г., когда вступил в действие Договор о ЕОУС. Основными его функциями является обеспечение исполнения и соблюдения права ЕС, разрешение споров между странамиучастницами и EC, а также между органами EC и осуществление защиты прав отдельных лиц. Следующим звеном является созданный в 1989 г. Трибунал первой инстанции. Ниццкий договор предусматривает учреждение еще одного звена судебной системы, которое будет включать в себя суды специальной юрисдикции - судебные палаты, рассматривающие отдельные категории правовых споров (служебные, в сфере интеллектуальной собственности и др.). Решения судебных палат в кассационном порядке могут быть обжалованы в Трибунал, а решения Трибунала - в Суд ЕC..$^{15}$

Счетная палата - образована в составе 27 аудиторов, назначаемых на 6 лет Советом после консультаций с Европарлментом. Ее задачи - проведение аудита, проверки всех доходов и расходов ЕС и содействие Европарламенту и Совету в их контроле за исполнением бюджета. По итогам каждого финансового года Счетная палата представляет отчет.

Европейский центральный банк (далее - ЕЦБ) - получил статут института ЕС в Лиссабонском соглашении. Он проводит единую денежную политику ЕС и наделен исключительным правом разрешать эмиссию денег в Евросоюзе. ЕЦБ возглавляет европейскую систему центральных банков.

\footnotetext{
${ }^{15}$ Подробнее о ЕСП см., напр., Безбах В.В., Беликова К.М. Решения Европейского суда правосудия - механизм сохранения и укрепления правопорядка ЕС. // Адвокат. - 2012. № 11. - С. 57-68; Они же. Европейский суд правосудия: общая характеристика и значение принципов, закрепляемых им в области частноправового регулирования (перепечатка). // Евразийский юридический журнал. - 2012. - № 6 (49). - С. 59-61.
} 
Европейский совет, как и ЕЦБ- получил статут института ЕС в Лиссабонском соглашении и представляет собой межправительственный орган. Его основная функция - обеспечивать ЕС необходимый импульс для его развития.

Полномочия по изданию нормативных актов предоставлены институтам ЕС (ст. 83 Договора). Совет и Комиссия облекают свои предписания в форму регламентов, директив, решений, рекомендаций и заключений.

Регламенты предназначены для общего применения, являются обязательными во всех частях и подлежат прямому применению во всех станах-участницах.

Директивы являются обязательными для каждой страны-участницы в отношении ожидаемого результата, однако формы и методы достижения этого результата оставляются на усмотрение стран-участниц.

Решения обязательны во всех частях для тех, в отношении кого они вынесены.

Рекомендации и заключения обязательными не являются.

Решения Суда справедливости по конкретным делам становятся прецедентами - образцами для принятия решений по аналогичным делам - и принимаются, как правило, по результатам рассмотрения жалоб, подаваемых на решения Комиссии ЕС. Суд ЕС в своих решениях обосновал следующий принцип толкования и применения права ЕС - его верховенство над правом стран-участниц и прямое действие. ${ }^{16}$

ЕЦБ издает нормативные акты в виде регламентов и ориентиров. Европейский совет не обладает полномочиями принимать нормативные акты, он принимает общие политические ориентиры и приоритеты, обязательные для поддержавших их государств и необязательные для остальных (ст. 15 Договора о ЕС). ${ }^{17}$

Институциональная структура МЕРКОСУР закреплена в нескольких актах: Асунсьонском

\footnotetext{
16 Право Европейского Союза: правовое регулирование торгового оборота. Учебное пособие. Под ред. В. В. Безбаха, А. Я. Капустина, В. К. Пучинского. - М.: ЗЕРЦАЛО, 2000. С. 54, 5; Основы европейского интеграционного права. [Текст]: учебник / авт. коллектив: А.Х. Абашидзе [и др.] ; под ред. д-ра юрид. наук, проф. А.Х. Абашидзе, д-ра юрид. наук, проф. А.О. Иншаковой. - М.: Изд-во «Юрист». - 2012. - С. 51-57.

17 Основы европейского интеграционного права. [Текст] : учебник / авт. коллектив: А.Х. Абашидзе [и др.] ; под ред. д-ра юрид. наук, проф. А.Х. Абашидзе, д-ра юрид. наук, проф. А.О. Иншаковой. - М.: Изд-во «Юрист». - 2012. - С. 40-42.
}

договоре,${ }^{18}$ Дополнительных протоколах к нему (Протоколе Оуро Прето 1994 г., ${ }^{19}$ Протоколе Оливос о разрешении споров в МЕРКОСУР 2002 г. ${ }^{20}$ и др.) и других актах (в том числе вторичного права, например, в решении Совета Общего рынка № 26/00 от 29 июня 2000 г. ${ }^{21}$ и др.), развивающих институциональную структуру МЕРКОСУР.

В настоящее время институциональная структура распадается на 3 уровня (см. схему 1 ниже и ее описание):

- базовый - Совет общего рынка, Группа общего рынка, Комиссия МЕРКОСУР по торговле, Парламент МЕРКОСУР, Комиссия постоянных представителей МЕРКОСУР, Постоянный трибунал для разрешения споров между государствами-членами,

- дополнительный, основанный на решениях органов МЕРКОСУР (Группы общего рынка, Совета общего рынка), - Трибунал по административным и трудовым делам, Социально-экономический консультативный Комитет, Административный секретариат и др.),

- дополнительный, основанный на иных, чем решения органов МЕРКОСУР актах, - рабочие субгруппы, технические комитеты. ${ }^{22}$ Эта система развивается, поскольку согласно положениям ст. 1 Протокола 1994 г. в целях дальнейшего осуществления интеграционного процесса по необходимости могут учреждаться вспомогательные органы.

${ }_{18}$ Tratado para la constitución de un mercado común entre la República Argentina, la República Federativa del Brasil, la República del Paraguay y la República Oriental del Uruguay. URL: http://www.mercosur.int/innovaportal/file/719/1/CMC_1991_ TRATADO_ES_Asunción.pdf (дата обращения: 31.07.10)

${ }^{19}$ Protocolo de Ouro Preto (Adicional al Tratado de Asunción sobre la Estructura Institucional del MERCOSUR). URL: http:// www.mercosur.int/innovaportal/file/721/1/cmc_1994_protocolo_ ouro_preto_es.pdf (дата обращения: 09.01.2013)

${ }^{20}$ Protocolo de Olivos para la Solución de Controversias en el MERCOSUR. URL: http://www.mercosur.int/innovaportal/ file/722/1/cmc_2002_protocolo_de_olivos_es.pdf(дата обращения: 09.01.2013) Подписан в г. Буэнос-Айрес 18 февраля 2002 г., вступил в силу с 1 января 2004 г., отменив собой Протокол Бразилии для разрешения споров

${ }^{21}$ Relanzamiento del MERCOSUR - Análisis de la estructura de órganos dependientes del Grupo Mercado Común y de la Comisión de Comercio/ MERCOSUR/CMC/DEC N ${ }^{\circ}$ 26/00. URL: http://www.sice.oas.org/trade/mrcsrs/decisions/Dec2600s. asp (дата обращения: 09.01.2013)

${ }^{22}$ См.: Estructura Institucional. // Mercado Común del Sur (MERCOSUR). URL: http://www.argentina.gob.ar/pais/100-mercado-comun-del-sur-mercosur.php (дата обращения: 20.11.2012) 
Estructura Institucional del MERCOSUR

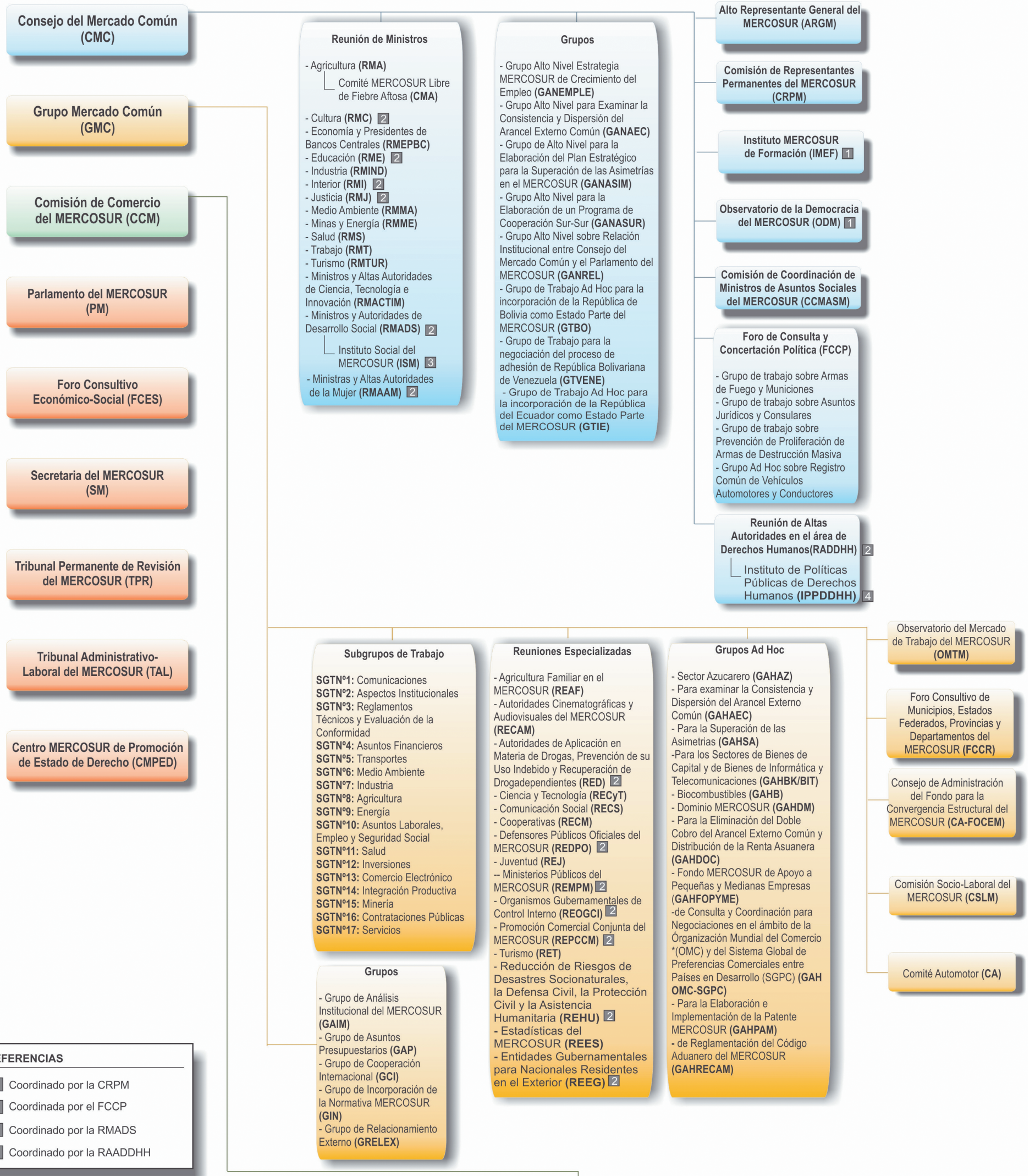


К числу постоянных органов, которые близки, по нашему мнению, институтам ЕС, образующим его институциональную систему, относятся: Административный секретариат, Парламент, Постоянный трибунал для разрешения противоречий между странами-участницами, Комиссия постоянных представителей.

Основные. В компетенцию Совета Общего рынка входит координация интеграционного процесса и принятие решений, гарантирующих решение задач, указанных в Асунсьонском договоре для достижения окончательного создания Общего рынка. В состав Совета общего рынка входят министры иностранных дел и министры экономики стран-участниц. Совет собирается столько раз, сколько сочтет необходимым, но не реже одного раза в полгода с участием президентов стран-участниц.

В рамках координации интеграционного процесса Совет осуществляет следующие полномочия: наблюдает за выполнением Асунсьонского договора, протоколов и соглашений, подписанных им в рамках предоставленных Договором полномочий; обеспечивает проведение политики МЕРКОСУР и принятие необходимых мер для создания Общего рынка; осуществляет права юридического лица, принадлежащие МЕРКОСУР; вправе заключать и подписывать соглашения от имени МЕРКОСУР с третьими странами, группами стран и международными организациями. Эти полномочия могут быть делегированы Группе Общего рынка в порядке, установленном подп. VII ст. 14 Протокола Оуро Прето. Совет также обладает правом принимать решения по предложениям, внесенным Группой Общего рынка; проводит встречи министров и принимает решения по заключенным на них соглашениям. Совет вправе создавать необходимые для его деятельности дополнительные органы, изменять или ликвидировать их. В случае необходимости Совет может вносить изменения в содержание принятых решений. Совет имеет право назначать директора административного секретариата Общего рынка и принимать решения по финансовым и бюджетным вопросам.

Группа Общего рынка - наделена исполнительной властью и полномочиями по внесению в Совет общего рынка предложений относительно программы действий и конкретных мер, гаранти- рующих продолжение развитие Общего рынка (ст. 13 Асунсьонского договора, ст. 2 Протокола Оуро Прето). В ее состав от каждой из стран входят по два члена (один на постоянной, второй - на временной основе), назначенных их правительствами из представителей министерств иностранных дел, экономики и центральных банков.

При подготовке и предложении конкретных мер, касающихся непосредственно ее деятельности, а также в случае необходимости может созывать представителей других государственных органов или представителей других органов Общего рынка. Группа Общего проводит плановые и чрезвычайные заседания столько раз, сколько сочтет необходимым, в порядке, установленном ее внутренним регламентом.

Основными функциями Группы Общего рынка являются: наблюдение в рамках ее компетенции за выполнением Асунсьонского договора, протоколов и соглашений, подписанных в рамках этого договора; принятие необходимых мер для выполнения принятых Советом Общего рынка решений, а также определение программы действий, гарантирующих продвижение развития Общего рынка. В связи с этим Группа наделена правом заключать соглашения от имени Общего рынка с третьими странами, группами стран и международными организациями при участии представителей всех государств-членов, по поручению Совета Общего рынка. При наличии полномочий для достижения данной цели Группа должна подписать упомянутые соглашения и может с разрешения Совета передавать указанные полномочия Комиссии по торговле Общего рынка.

Группа Общего рынка вправе создавать, изменять или ликвидировать рабочие органы, такие, например, как рабочие подгруппы, если это необходимо для выполнения ее задач. Она принимает бюджет и ежегодный отчет, представленный Административным секретариатом Общего рынка, а также принимает решения по финансовым и бюджетным вопросам на основе выделенных Советом Общего рынка направлений. Группа вправе организовывать встречи Совета Общего рынка, а также составлять доклады и проводить исследовательские работы по просьбе Совета Общего рынка. На нее возложена обязанность представлять свой внутренний регламент на рассмотрение Совету Общего рынка. 
За Группой Общего рынка закреплено право выбора директора Административного секретариата МЕРКОСУР, надзора за деятельностью Административного секретариата, а также утверждения внутреннего регламента Комиссии по торговле и Социально-экономического консультативного комитета.

Комиссия МЕРКОСУР по торговле, ${ }^{23}$ деятельность которой нацелена на содействие Группе Общего рынка в углублении процессов интеграции, осуществляет надзор за выполнением соглашений по общей торговой политике стран МЕРКОСУР, а также соглашений со странами, не входящими в МЕРКОСУР, и международными организациями (ст. 16 и 19 Протокола Оуро Прето). Кроме того, в порядке, предусмотренном приложением к протоколу Оуро Прето, она рассматривает жалобы по вопросам, входящим в ее компетенцию, полученные от странучастниц и физических (или юридических) лиц, подаваемые ее национальными отделениями по основаниям, предусмотренным в ст. 1 и 39 Протокола Оливос 2002 г. ${ }^{24}$

Комиссия по торговле состоит из четырех постоянных членов и четырех непостоянных членов от каждой страны-участницы. Ее заседания проводятся не реже одного раз в месяц. В случае необходимости, по просьбе Группы Общего рынка или одного из государств-членов Комиссия может заседать несколько раз в месяц.

Комиссии по торговле вправе рассматривать и принимать решения по предложениям странучастниц, касающимся установления и применения общего таможенного тарифа, а также актов по общей торговой политике, способствующей укреплению таможенного союза и вносить предложения по этим вопросам Группе Общего рынка.

В функции Комиссии входит также предоставление информации Группе Общего рынка о выполнении соглашений по общей торговой политике, о рассмотрении полученных предложений, касающихся ее, и о решениях, принятых по этим

\footnotetext{
${ }^{23}$ До принятия Протокола Оуро Прето Комиссия действовала на основании решения Совета Общего рынка № 09/94.

${ }^{24}$ Положения главы 1 регламентируют процедуру разрешения споров между странами-участницами МЕРКОСУР; глава 11,порядок рассмотрения жалоб, поданных на соответствующие страны частными лицами.
}

предложениям, а также о принятии новых или изменению существующих норм по вопросам торговли и таможни и о пересмотре тарифных квот. Комиссии вменяется в обязанность оказывать помощь Группе Общего рынка по любым вопросам, связанным с общей торговой политикой.

Для выполнения своих функций Комиссия по торговле уполномочена создавать технические комитеты и осуществлять руководство и контроль за их деятельностью.

Во исполнение полномочий, предоставленных Совету Общего рынка решением Совета № 26/0025 в 2000 г. была изменена структура рабочих органов Группы Общего рынка и технических комитетов Комиссии МЕРКОСУР по торговле, закрепленная Протоколом Оуро Прето. Согласно положениям решения Совета часть групп ad hoc Группы Общего рынка была преобразована в рабочие группы; часть существующих рабочих групп объединена; часть - упразднена; была упразднена и часть технических комитетов, созданных для выполнения своих функций Комиссией по торговле: например, Комитет по недобросовестной конкуренции, Комитет по регулированию политики в области конкуренции и др. и создан Комитет по защите и охране в области торговли (Comite de Defensa Comercial y Salvaguardias).

Парламент МЕРКОСУР - является представительным органом всего идеологического и политического разнообразия народов странучастниц Общего рынка, призван содействовать распространению демократии, свободы мира, ценностей МЕРКОСУР и пр. (ст. 2 Протокола об учреждении Парламента МЕРКОСУР ${ }^{26}$ ). Согласно ст. 1 Протокола об учреждении Парламента МЕРКОСУР Парламент состоит из представителей, избираемых всеобщим прямым и тайным голосованием согласно положениями внутреннего законодательства каждой страны-участницы МЕРКОСУР и настоящего Протокола. Парламент

\footnotetext{
${ }^{25}$ Restructuración de los órganos dependientes del Grupo Mercado Común y de la Comisión de Comercio del MERCOSUR. MERCOSUR/CMC/DEC N 59/00. URL: http://www.sice.oas. org/trade/mrcsrs/decisions/dec5900s.asp (дата обращения: 09.01.2013)

${ }^{26}$ Protocolo Constitutivo del Parlamento del MERCOSUR. URL: http://www.mercosur.int/innovaportal/file/1104/1/2005_protocoloparlamentomcs_es.pdf (дата обращения: 09.01.2013)
} 
представляет собой орган, состоящий из одной палаты, принципы его деятельности и полномочия устанавливаются настоящим Протоколом.

В 2006 г. он заменил Парламентскую комиссию, ${ }^{27}$ состоявшую из равного числа парламентских представителей от каждого из государств-членов МЕРКОСУР, назначавшихся национальными парламентами согласно их внутренней процедуре и бывшего, по сути, межпарламентским органом. Члены Парламентской комиссии назначались национальными парламентами стран-участниц согласно их внутренней процедуре. Парламентская комиссия должна была прилагать усилия для скорейшего вступления в силу норм, принятых органами МЕРКОСУР и содействовать гармонизации законодательства стран-участниц в соответствии с требованиями процесса интеграции. В случае необходимости Совет МЕРКОСУР мог предлагать Парламентской комиссии рассматривать приоритетные с его точки зрения вопросы, а Парламентская комиссия, в свою очередь, могла давать свои рекомендации через Группу МЕРКОСУР Совету МЕРКОСУР.

Парламенту МЕРКОСУР надлежит следить за: соблюдением норм права МЕРКОСУР, поддержанием в странах-участницах демократического режима правления, ежегодно публиковать отчеты о состоянии прав человека в МЕКРКОСУР, запрашивать у иных органов МЕРКОСУР отчеты и мнения о ходе интеграции, издавать декларации, рекомендации и отчеты по вопросам, связанным с развитием интеграции в МЕРКОСУР и т.д. (ст. 4 Протокола об учреждении Парламента МЕРКОСУР).

Комиссия постоянных представителей, создана в 2003 г., ее председатель представляет МЕРКОСУР в отношениях во вне.

Постоянный трибунал для разрешения споров между государствами-членами правомочный пересматривать решения трибуналов $a d$ hoc и рассматривать дела по существу в первой инстанции.

Надо сказать, что исторически процедура разрешения споров согласно Протоколу Оливос 2002 г. (равно как и согласно действовавшему

\footnotetext{
${ }^{27}$ Идея создать Парламент МЕРКОСУР нашла закрепление в решении Совета Общего рынка № 49/2004 от 16 декабря 2004 г. (MERCOSUR/CMC/DEC. No 49/04: Parlamento del MERCOSUR.).
}

ранее Протоколу Бразилии) предусматривала прямые переговоры (гл. 4). В случае, если такие переговоры не оказывались успешными или приводили лишь к частичному разрешению противоречий, любая страна-участница могла сразу обратиться к рассмотрению спора по существу в третейском суде.

Система разрешения споров между странами-участницами МЕРКОСУР предусматривала, таким образом, сначала только арбитраж ad hoc, a затем, впервые в Протоколе Оливос была введена возможность разрешения споров в Постоянном трибунале (Tribunal Permanente de Revisión), правомочном пересматривать решения трибуналов ad hoc и рассматривать дела по существу в качестве суда первой инстанции.

По обоюдному согласию, а также в случае, когда по окончании прямых переговоров об этом просила страна-участница МЕРКОСУР, не являвшаяся стороной, участвовавшей в разрешении спора, страны-участницы могли представить дело на рассмотрение Группы Общего рынка.

Последняя, заслушивая объяснения сторон и, в случае необходимости - мнения экспертов, ограничивалась дачей рекомендаций или представляла заключение (ст. 6 и 7 Протокола Оливос) сторонам, но не разрешала спор. В этом случае рассмотрение дела в арбитраже могло быть приостановлено только по соглашению сторон, в отношениях которых возникли противоречия. В случае недостижения урегулирования стороны сообщали в Административный секретариат о желании прибегнуть к арбитражу (гл. 6). Такая процедура применяется и сейчас.

Арбитры Постоянного трибунала действуют на постоянной основе и в случае необходимости приступают к выполнению своих обязанностей. Трибунал состоит из 5 арбитров - каждая страна-участница назначает одного арбитра и одного его заместителя на 2 года, каждый из них может дважды быть назначен повторно; пятый назначается странами-участницами единогласно на 3 года (из списка из 8 кандидатов, по двое от каждого государства-члена; каждый должен быть гражданином государств МЕРКОСУР) и не может быть избран повторно, если иное не установлено их соглашением. Пятый арбитр может быть гражданином любой из стран-участниц - не только полноправных, но и ассоциированных. 
В случае недостижения единогласия указанный арбитр избирается из представленного списка Административным секретариатом по жребию. ${ }^{28}$ Страны-участницы могут установить иные критерии назначения пятого арбитра. В случае возникновения противоречий между двумя государствами Трибунал действует в составе 3 арбитров, в случае участия более двух государств - пяти. Страны-участницы могут установить иные критерии функционирования Трибунала. Решением Совета №26/04 от 7 июля 2004 г. ${ }^{29}$ впервые были назначены арбитры этого трибунала.

Жалоба о пересмотре решения трибунала $a d$ hoc может быть подана в течение 15 дней с момента его вынесения, решение пересматривается только по вопросам права и толкования юридических понятий, использованных в решении трибунала; решения, вынесенные на основании принципов $e x$ aequo et bono, обжалованию не подлежат (ст. 17 Протокола). Трибунал может оставить решение трибунала ad hoc без изменений, изменить или отменить его. Решения окончательны, не могут быть обжалованы и превалируют над решениями трибуналов. Все решения обязательны для сторон, в отношении которых вынесены (ст. 26 Протокола), а страны-участницы обязуются признавать обязательность юрисдикции указанных судов и Трибунала (ст. 33 Протокола).

Дополнительные (некоторые). Социальноэкономический консультативный Комитет представительный орган социального и экономи-

\footnotetext{
${ }^{28}$ Указанный порядок избрания пятого арбитра воспринят на концептуальном уровне из Конституции Аргентины, предусматривающей в ст. 50 что депутаты Парламента избираются сроком на четыре года, но каждые два года депутатский корпус должен обновляться на половину; по этой причине депутаты первого Законодательного собрания, после того как они соберутся, должны тянуть жребий, для того, чтобы решить, кто покинет собрание по истечении первого двухгодичного периода. - Беликова К.М., Ковалев С.И. Перевод конституции Аргентины. // Конституции государств Америки: В 3 т. / под ред. д.ю.н., проф. Т.Я. Хабриевой. - Т. 3: Южная Америка. - М.: Институт Законодательства и сравнительного правоведения при Правительстве Российской Федерации, 2006. - C. 14-50 (1168 c.).

${ }^{29}$ Designación de los árbitros del tribunal permanente de re-

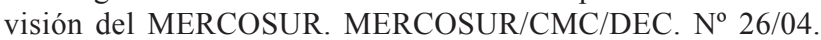
URL: http://www.mercosur.int/msweb/Normas/normas_web/ Decisiones/ES/DEC\%20026_004_Tribunal_Perman_Revis Acta\%2001_04.PDF (дата обращения: 09.01.2013)
}

ческого секторов - состоит из равного количества представителей каждого государства-члена, имеет консультативную функцию, предлагает свои рекомендации и представляет свой внутренний регламент на утверждение Группе общего рынка.

Административный секретариат - орган оперативной поддержки - отвечает за предоставление услуг другим органам МЕРКОСУР, находится в г. Монтевидео. В обязанности Административного секретариата входят: хранение документации МЕРКОСУР, ее публикация и распространение информации о принятых нормах в рамках МЕРКОСУР в издаваемом официальном бюллетене Общего рынка; осуществление (совместно с государствами-членами МЕРКОУСР) аутентичных переводов на испанский и португальский языки всех принятых решений органов институциональной структуры Общего рынка.

Административный секретариат также помогает организации проведения встреч Совета, Группы, Комиссии по торговле МЕРКОСУР и, при необходимости, других органов, если эти встречи проводятся в месте их постоянного нахождения, или оказывает поддержку государству, на территории которого они проводятся, если встречи проводятся вне этого места.

Административный секретариат обязан регулярно предоставлять информацию государствам-членам о мерах, принятых каждым из государств-членов, для приведения в соответствие своего внутреннего законодательства с нормами, принятыми органами Общего рынка. Административный секретариат также выполняет обязанности, возложенные на него Протоколом Оливос (ст. 9 Протокола), в том числе регистрирует списки экспертов и арбитров от каждой страны-участницы и т.п.

С 2003 г. техническую помощь и рекомендации органам МЕРКОСУР выдает сформированное из представителей полноправных стран-участниц МЕРКОСУР Совещательнотехническое подразделение (Sector Asesoria Tecnica) Административного секретариата.

Консультативный комитет по делам муниичипий, федеративных государств, провинций и департаментов МЕРКОСУР - в целях содействия диалогу и сотрудничеству муниципальных, провинциальных и департаментских органов власти преобразован решением Совета 
Общего рынка № 41/0430 от 16 декабря 2004 г. из проводимых в рамках Группы Общего рынка специализированных заседаний по вопросам деятельности муниципий и управлений.

Фонд для структурной конвергениии МЕРКОСУР - учрежден решением Совета Общего рынка № 45/200431 с целью финансирования программ, содействующих структурной конвергенции, повышению конкурентоспособности и сглаживанию неравномерности развития менее развитых в экономическом плане регионов и стран-участниц МЕРКОСУР.

Полномочия по изданию нормативных актов и иных (ненормативных) предписаний в рамках МЕРКОСУР предоставлены его институтам - органам межправительственного характера - Совету и Группе Общего рынка, Комиссии МЕРКОСУР по торговле и Парламенту МЕРКОСУР и Постоянному трибуналу.

Совет облекает свои предписания в форму обязательных для стран-участниц МЕРКОСУР решений (decisiones - ст. 9 Протокола).

В форме решений оформляются следующие акты, являющиеся составной частью Асунсьонского договора: протоколы (protocolos - например, Протокол о защите конкуренции в МЕРКОСУР); дополнительные протоколы (protocolo adicional - например, Дополнительный протокол об институциональной структуре МЕРКОСУР - Протокол Оуро Прето); приложения к Протоколам и Асунсьонскому договору (anexos - например, Приложение к Протоколу о защите конкуренции в МЕРКОСУР); соглашения (acuerdos - например, Соглашение о международном коммерческом арбитраже МЕРКОСУР) - международные по своей сути и международными не являющиеся (например, Соглашение, регламентирующее Протокол о защите конкуренции в МЕРКОСУР).

\footnotetext{
${ }^{30}$ Foro consultivo de municipios, estados federados, provincias y departamentos del MERCOSUR. MERCOSUR/CMC/ DEC. $N^{\circ}$ 41/04. URL: http://www4.planalto.gov.br/saf-fccr/ fccr-mercosul/documentos-oficiais/documento-4104.pdf (дата обращения: 09.01.2013)

${ }^{31}$ Fondo para la convergencia estructural del MERCOSUR. MERCOSUR/CMC/DEC. No 45/04. URL: http://www.mercosur.int/msweb/Normas/normas_web/Decisiones/ES/DEC $\% 20$ 045-004-Fondo\%20Estructural-ES_Acta\%202-04.PDF (дата обращения: 09.01.2013)
}

Группа Общего рынка издает обязательные для стран-участниц постановления (regulaciones - ст. 15 Протокола).

Комиссия издает директивы (directivas) акты, по вопросам, связанным с проведением общей торговой политики стран-участниц МЕРКОСУР, обязательные для стран-участниц, и рекомендации (propuestas) - проекты и инициативы, представляемые исполнительному органу МЕРКОСУР в рамках деятельности по осуществлению надзор за выполнением соглашений по общей торговой политике (ст. 20 Протокола).

Парламент издает рекомендательные декларации (declaraciones), рекомендации (recomendaciones) и отчеты (informes) по вопросам, связанным с развитием интеграции в МЕРКОСУР.

Постоянный трибунал, пересматривая решения трибуналов ad hoc и рассматривая дела по существу в качестве суда первой инстанции, выносит решения, действующие только в отношении сторон, участвующих в деле.

Вышеизложенное позволяет сделать некоторые общие выводы. Институциональная структура МЕРКОСУР и система издаваемых органами (институтами) МЕРКОСУР актов на сегодняшний день уже довольно развита. Как можно заметить вектор ее развития соответствует вектору развития институтов и органов ЕC, что позволяет, на наш взгляд, говорить о некоторой «евроморфности» южноамериканской модели институциональной структуры и системы правовых актов с элементами самобытности латиноамериканских государств. Так, выявленный вектор развития состоит, прежде всего, в осознании необходимости создания постоянно действующих органов, как, например, Постоянный трибунал, Парламент МЕРКОСУР, Секретариат МЕРКОСУР, придающих системе устойчивость и способность быстрого реагирования на появляющиеся вызовы. Самобытность же проявляется в потребности развивать функционал институтов (органов) и механизм их действия исходя из реалий латиноамериканских стран (например, включение в полномочия Парламента МЕРКОСУР функции по поддержанию в странахучастницах демократического режима правления, ежегодной публикации отчетов о состоянии прав человека в МЕКРКОСУР и т.д.; назначение 5-го арбитра Постоянного трибунала по жребию, характерное для Аргентины и пр.). 


\section{Библиография:}

1. Безбах В.В., Беликова К.М. Европейский суд правосудия: общая характеристика и значение принципов, закрепляемых им в области частноправового регулирования (перепечатка). // Евразийский юридический журнал. - 2012. - № 6 (49). - С. 59-61.

2. Безбах В.В., Беликова К.М. Решения Европейского суда правосудия - механизм сохранения и укрепления правопорядка ЕС. // Адвокат. - 2012. - № 11. - С. 57-68.

3. Безбах В.В., Беликова К.М. Что заставляет латиноамериканцев объединяться? Образование Южноамериканского Общего рынка и его развитие. // Внешнеторговое право. - 2006. - № 1(6). - C. 8-12.

4. Беликова К.М. На пути к единому рынку в Южной Америке: факторы интеграции в экономике и праве. // Вестник Российского университета дружбы народов. Серия «Юридические науки». 2005. - № 1. - С. 83-89.

5. Беликова К.М. Общий рынок в Европе: интеграция и дифференциация. // Международное публичное и частное право. - 2005. - № 1 (22). - С. 14-17.

6. Беликова К.М. Особенности правовой охраны конкурентной среды в Североамериканской зоне свободной торговли (НАФТА). // Сравнительное право и проблемы частноправового регулирования: Материалы научной конференции аспирантов кафедры гражданского и трудового права юридического факультета РУДН. Москва, 25 января 2008 г. Выпуск 8./ Сост. В.В. Безбах, Е.П. Ермакова, К.М. Беликова. - М.: МАКС Пресс, 2008. - С. 29-32.

7. Беликова К.М. Правовое регулирование торгового оборота и кодификация частного права в странах Латинской Америки. Монография / К.М. Беликова. - М.: Юстицинформ - 2010. - С. С. 87-102 (480 с.).

8. Конституции государств Америки: В 3 т. / под ред. д.ю.н., проф. Т.Я. Хабриевой. - Т. 3: Южная Америка. - М.: Институт Законодательства и сравнительного правоведения при Правительстве Российской Федерации, 2006. - С. 14-50 (1168с.).

9. Моисеев А. Демократия дала сбой в Парагвае. // Международная жизнь. 16/07/2012. URL: http://ref. interaffairs.ru/read.php?item=8610 (дата обращения: 09.01.2013)

10. Основы европейского интеграционного права. [Текст] : учебник / авт. коллектив: А.Х. Абашидзе [и др.] ; под ред. д-ра юрид. наук, проф. А.Х. Абашидзе, д-ра юрид. наук, проф. А.О. Иншаковой. - М.: Изд-во «Юрист». - 2012. -

11. Право Европейского Союза: правовое регулирование торгового оборота. Учебное пособие. / под ред. В.В. Безбаха, А.Я. Капустина, В.К. Пучинского. - М.: ЗЕРЦАЛО, 2000.

12. Право Европейского Союза: учебн. пособие /С.Ю. Кашкин [и др.]; отв. ред. С.Ю. Кашкин. - М.: ТК Велби, Изд-во Проспект, 2008.

13. Право Европейского Союза: Учебник для вузов / под ред. С.Ю. Кашкина. - М.: Юристъ, 2002.

14. Топорнин Б.Н. Европейское право: Учебник. - М.: Юристь, 2001.

15. Энтин М.Л. Суд Европейских сообществ. Правовые формы обеспечения западноевропейской интеграции. - М., 1987.

16. Alonso Casellas C., Bozzo C., Ferro G.S., Gos L.A., Stabile M.R. Solución de controversias en los sistemas de integración. El caso del MERCOSUR. SERIE INAP-AAG. DNEYD - CEPAS. P. 16-32.

17. Consolidated versions of the Treaty on European Union and the Treaty on the functioning of the European Union. // OJ C 83 of 30.3.2010. URL: http://eur-lex.europa.eu/JOHtml.do?uri=OJ:C:2010:083:SOM:EN: HTML (дата обращения: 05.01.2013)

18. Designación de los árbitros del tribunal permanente de revisión del MERCOSUR. MERCOSUR/CMC/ DEC. No 26/04. URL: http://www.mercosur.int/msweb/Normas/normas_web/Decisiones/ES/DEC\%20 026_004_Tribunal_Perman_Revis_Acta\%2001_04.PDF (дата обращения: 09.01.2013)

19. Documentación del Seminario "Las normas de derecho originario y derivado del MERCOSUR. Su incorporación a los ordenamientos de los estados partes." Secretaría Administrativa del Mercosur (SAM), Montevideo, República Oriental del Uruguay 26 y 27 de septiembre de 2002. 
20. Eduardo Arce. Polémica en torno a la firma del Protocolo de Montevideo en el Mercosur. // E`a. Periodico de Interpretacion y Analisys. Enero 11, 2012. URL: http://ea.com.py/polemica-en-torno-a-la-firma-delprotocolo-de-montevideo-en-el-mercosur/ (дата обращения: 09.01.2013)

21. Estructura Institucional. // Mercado Común del Sur (MERCOSUR). URL: http://www.argentina.gob.ar/ pais/100-mercado-comun-del-sur-mercosur.php (дата обращения: 20.11.2012)

22. Fondo para la convergencia estructural del MERCOSUR. MERCOSUR/CMC/DEC. N $\mathrm{N}^{\mathrm{o}} 45 / 04$. URL: http://www.mercosur.int/msweb/Normas/normas_web/Decisiones/ES/DEC\%20045-004-Fondo\%20 Estructural-ES_Acta\%202-04.PDF (дата обращения: 09.01.2013)

23. Foro consultivo de municipios, estados federados, provincias y departamentos del MERCOSUR. MERCOSUR/CMC/DEC. N ${ }^{o}$ 41/04. URL: http://www4.planalto.gov.br/saf-fccr/fccr-mercosul/documentos-oficiais/documento-4104.pdf (дата обращения: 09.01.2013)

24. Lavopa H. J. La dimensión juridica de la integración. // Contribuciones. - Buenos Aires, 1996. - A. 13, \# 4. - P. 149-189.

25. Protocolo Constitutivo del Parlamento del MERCOSUR. URL: http://www.mercosur.int/innovaportal/ file/1104/1/2005_protocoloparlamentomcs_es.pdf (дата обращения: 09.01.2013)

26. Protocolo de Adhesión del Estado Plurinacional de Bolivia al MERCOSUR. 7/12/2012. URL: http://www. mercosur.int/innovaportal/file/2485/1/protocolo_adhesion_bolivia_al_mercosur.pdf (дата обращения: 09.01.2013)

27. Protocolo de Montevideo sobre Compromiso con la Democracia en el MERCOSUR (Ushuaia II). 20/12/2012. URL: http://www.mercosur.int/innovaportal/file/2485/1/ushuaia_ii.pdf (дата обращения: 09.01.2013).

28. Protocolo de Olivos para la Solución de Controversias en el MERCOSUR. URL: http://www.mercosur. int/innovaportal/file/722/1/cmc_2002_protocolo_de_olivos_es.pdf (дата обращения: 09.01.2013)

29. Protocolo de Ouro Preto (Adicional al Tratado de Asunción sobre la Estructura Institucional del MERCOSUR). URL: http://www.mercosur.int/innovaportal/file/721/1/cmc_1994_protocolo_ouro_preto_ es.pdf (дата обращения: 09.01.2013)

30. Relanzamiento del MERCOSUR - Análisis de la estructura de órganos dependientes del Grupo Mercado Común y de la Comisión de Comercio/ MERCOSUR/CMC/DEC N 26/00. URL: http://www.sice.oas. org/trade/mrcsrs/decisions/Dec2600s.asp (дата обращения: 09.01.2013)

31. Restructuración de los órganos dependientes del Grupo Mercado Común y de la Comisión de Comercio del MERCOSUR. MERCOSUR/CMC/DEC N 59/00. URL: http://www.sice.oas.org/trade/mrcsrs/decisions/dec5900s.asp (дата обращения: 09.01.2013)

32. Ruesga Santos, M., Heredero, $M^{a}$ Isabel y Fujii, Gerardo, Europa e Iberoamerica: dos escenarios de integración económica, Editorial Parte Luz, Madrid, 1998.

33. Tratado para la constitución de un mercado común entre la República Argentina, la República Federativa del Brasil, la República del Paraguay y la República Oriental del Uruguay. URL: http://www.mercosur. int/innovaportal/file/719/1/CMC_1991_TRATADO_ES_Asunción.pdf (дата обращения: 31.07.10)

34. Treaty on European Union (consolidated text). // Official Journal C 325 of 24 December 2002. URL: http:// europa.eu.int/eur-lex/en/treaties/dat/amsterdam.html (дата обращения: 10.02.2006)

35. Venezuela se incorporó formalmente al Mercosur. 31 de julio de 2012. URL: http://www.lanacion.com. ar/1494926-todo-listo-para-que-venezuela-se-incorpore-al-mercosur (дата обращения: 09.01.2013)

\section{References (transliteration):}

1. Bezbakh V.V., Belikova K.M. Evropeyskiy sud pravosudiya: obshchaya kharakteristika i znachenie printsipov, zakreplyaemykh im v oblasti chastnopravovogo regulirovaniya (perepechatka). // Evraziyskiy yuridiche-skiy zhurnal. - 2012. - № 6 (49). - S. 59-61. 
2. Bezbakh V.V., Belikova K.M. Resheniya Evropeyskogo suda pravosudiya - mekhanizm sokhraneniya i ukrepleniya pravoporyadka ES. // Advokat. - 2012. - № 11. - S. 57-68.

3. Bezbakh V.V., Belikova K.M. Chto zastavlyaet latinoamerikantsev ob'edinyat'sya? Obrazovanie Yuzhnoamerikanskogo Obshchego rynka i ego razvitie. // Vneshnetorgovoe pravo. - 2006. - № 1(6). - S. 8-12.

4. Belikova K.M. Na puti k edinomu rynku v Yuzhnoy Amerike: faktory integratsii v ekonomike i prave. // Vestnik Rossiyskogo universiteta druzhby narodov. Seriya «Yuridicheskie nauki». - 2005. - № 1. - S. 83-89.

5. Belikova K.M. Obshchiy rynok v Evrope: integratsiya i differentsiatsiya. // Mezhdunarodnoe publich-noe i chastnoe pravo. - 2005. - № 1 (22). - S. 14-17.

6. Belikova K.M. Osobennosti pravovoy okhrany konkurentnoy sredy v Severoamerikanskoy zone svobodnoy torgovli (NAFTA). // Sravnitel'noe pravo i problemy chastnopravovogo regulirovaniya: Materia-ly nauchnoy konferentsii aspirantov kafedry grazhdanskogo i trudovogo prava yuridicheskogo fakul'teta RUDN. Moskva, 25 yanvarya 2008 g. Vypusk 8./ Sost. V.V. Bezbakh, E.P. Ermakova, K.M. Belikova. M.: MAKS Press, 2008. - S. 29-32.

7. Belikova K.M. Pravovoe regulirovanie torgovogo oborota i kodifikatsiya chastnogo prava v stranakh Latinskoy Ameriki. Monografiya / K.M. Belikova. - M.: Yustitsinform - 2010. - S. S. 87-102 (480 s.).

8. T.Ya. Khabrieva. Konstitutsii gosudarstv Ameriki: V 3 t. / pod red. d.yu.n., prof. T.Ya. Khabrievoy. - T. 3: Yuzhnaya Amerika. - M.: Institut Zakonodatel'stva i sravnitel'nogo pravovedeniya pri Pravitel'stve Rossiyskoy Federatsii, 2006. - S. 14-50 (1168 s.).

9. Moiseev A. Demokratiya dala sboy v Paragvae. // Mezhdunarodnaya zhizn'. 16/07/2012. URL: http://ref. interaffairs.ru/read.php?item $=8610$ (data obrashcheniya: 09.01.2013)

10. A.Kh. Abashidze Osnovy evropeyskogo integratsionnogo prava. [Tekst] : uchebnik / avt. kollektiv: A.Kh. Abashidze [i dr.] ; pod red. d-ra yurid. nauk, prof. A.Kh. Abashidze, d-ra yurid. nauk, prof. A.O. Inshakovoy. - M.: Izd-vo «Yurist». - 2012. -

11. V.V. Bezbakh Pravo Evropeyskogo Soyuza: pravovoe regulirovanie torgovogo oborota. Uchebnoe posobie. / pod red. V.V. Bezbakha, A.Ya. Kapustina, V.K. Puchinskogo. - M.: ZERTsALO, 2000.

12. S.Yu. Kashkin. Pravo Evropeyskogo Soyuza: Uchebnik dlya vuzov / pod red. S.Yu. Kashkina. - M.: Yurist', 2002.

13. Topornin B.N. Evropeyskoe pravo: Uchebnik. - M.: Yurist', 2001.

14. Entin M.L. Sud Evropeyskikh soobshchestv. Pravovye formy obespecheniya zapadnoevropeyskoy integratsii. - M., 1987. 